\title{
School Education in West Bengal and Kerala: A Comparative Perspective
}

\section{Sheikh Imran Pervez}

Research Scholar, Department of Education, Jadavpur University, Kolkata, India

Corresponding author: imran.pervez111@gmail.com

Received: $12-01-2021$

Revised: $17-03-2021$

Accepted: 14-04-2021

\begin{abstract}
Both West Bengal and Kerala have significant influence in socio-economic and political field of India. Therefore a comparative study of the status of school education between these two is very significant in Indian context. The objective of the study was to comparatively analyse the status of school education of West Bengal and Kerala in terms of school profile, school infrastructure, teaching and non-teaching staff for the period of 2016-2017 based on DISE data. The study explored interesting aspects of the status of school education in both the states. It made some important suggestions for the stakeholders.
\end{abstract}

Keywords: West Bengal, Kerala, School education, Status, Comparative study

As per 2011 census, West Bengal is one of the most densely populated state in the country with a population density of 1029 persons per square $\mathrm{km}$. Though the pressure of population is high, West Bengal has made a considerable progress in the field of literacy and school education. At present there are 23 districts in West Bengal. According to Census 2011, the literacy rate of West Bengal is 77.1 percent. It is good enough against the national literacy rate that is 74.0 percent (Census, 2011). On the other hand, at present there are 14 districts in Kerala. Kerala is the pathfinder for the rest of India in educational advancement. Kamalamma (1969) conducted a study on "History and Problems of Primary Education in Kerala" revealing how the state emerged as progressive one in education. The state achieved first position in India in literacy rate. In 2011 it has attained the highest effective literacy rate of 93.9 percent. The female literacy rate is 92.0 percent in Kerala as compared to 65.5 percent at the National level. The male literacy rate is 96.0 percent in Kerala as compared to 82.1 percent at the National level (Census, 2011). Kerala is the only state in India where Total Literacy campaign (TLC) has been successfully implemented. In both the states, Schools are run either the state government school education department or by private organizations, including religious institutions. The schools are affiliated with the Indian Certificate of Secondary Education (ICSE) or the Central Board for Secondary Education (CBSE) or National Institute of Open Schooling (NIOS) or the state education board. English is the language of instruction in most of the private schools in both states, but government run schools offer both English and regional languages as medium of instruction.

Despite Government initiating several sound policies, education does not flourish equally in all the states and union territories of India. Among all the states in India Kerala is the in the $1^{\text {st }}$ position with literacy rate $93.91 \%$ whereas West Bengal secures $20^{\text {th }}$ position with literacy rate of $77.08 \%$. Both the states have significant influence in socio-

How to cite this article: Pervez, S.I. (2021). School Education in West Bengal and Kerala: A Comparative Perspective. Educational Quest: An Int. J. Edu. Appl. Soc. Sci., 12(1): 09-14.

Source of Support: None; Conflict of Interest: None (क) क 
economic and political field of India. Therefore a comparative study of the status of school education between West Bengal and Kerala is very significant in Indian context.

\section{Objective of the Study}

Following objective were taken into consideration for the present study-

(i) To comparatively analyse the status of school education of West Bengal and Kerala in terms of school profile, school infrastructure, teaching and non-teaching staff.

\section{Delimitation of the Study}

The present study was delimited to the following-

1. It was based on secondary data.

2. In the sphere of status of school education only the school profile, school infrastructure, teaching-non teaching stuff were taken into account.

3. Only 2016-2017 period was considered for exploring this study.

\section{Database of the Study}

Different sources of secondary data have been consulted to compare the status of school education between West Bengal and Kerala. The main sources for the information are:

"Elementary Education in India: State Report Cards 2016-17", District Information System for Education" (DISE), National University for Educational Planning and Administration (NUEPA).

"Elementary Education in India: District Report Cards 2016-17" (Volume I and Volume II), District Information System for Education" (DISE), National University for Educational Planning and Administration (NUEPA).

"School Education in India- Flash Statistics 2016-17", District Information System for Education" (DISE), National University for Educational Planning and Administration (NUEPA).

"Census of India-2011", Registrar General of India.

\section{School Education in West Bengal and Kerala}

West Bengal witnessed steady consistency in literacy rate in the period of 2016-2017. According to Census 2011, overall literacy rate of West Bengal was 77.1 percent which was slightly higher than the national overall literacy rate i.e. 74.0 per cent.

Table 1: Literacy Rate in the Districts of West Bengal

\begin{tabular}{lllll}
\hline District & $\begin{array}{l}\text { Population } \\
\text { (000's) }\end{array}$ & $\begin{array}{l}\text { Male } \\
\text { Literacy } \\
\text { Rate }\end{array}$ & $\begin{array}{l}\text { Female } \\
\text { Literacy } \\
\text { Rate }\end{array}$ & $\begin{array}{l}\text { Total } \\
\text { Literacy } \\
\text { Rate }\end{array}$ \\
\hline Bankura & 3596 & 71.0 & 81.0 & 60.4 \\
Barddhaman & 7724 & 77.2 & 83.4 & 70.5 \\
Birbhum & 3502 & 70.9 & 77.4 & 64.1 \\
\hline
\end{tabular}

Table 1. (cont.)

\begin{tabular}{|c|c|c|c|c|}
\hline District & $\begin{array}{l}\text { Population } \\
\text { (000's) }\end{array}$ & $\begin{array}{l}\text { Male } \\
\text { Literacy } \\
\text { Rate }\end{array}$ & $\begin{array}{l}\text { Female } \\
\text { Literacy } \\
\text { Rate }\end{array}$ & $\begin{array}{l}\text { Total } \\
\text { Literacy } \\
\text { Rate }\end{array}$ \\
\hline $\begin{array}{l}\text { Dakshin } \\
\text { Dinajpur }\end{array}$ & 1671 & 73.9 & 79.6 & 67.8 \\
\hline Darjiling & 1842 & 79.9 & 85.9 & 73.7 \\
\hline Howrah & 4842 & 83.9 & 87.7 & 79.7 \\
\hline Hoogly & 5520 & 82.6 & 87.9 & 77.0 \\
\hline Jalpaiguri & 3870 & 73.8 & 80.6 & 66.7 \\
\hline Koch Bihar & 2823 & 75.5 & 81.5 & 69.1 \\
\hline Kolkata & 4487 & 87.1 & 89.1 & 85.0 \\
\hline Maldah & 3998 & 62.7 & 67.3 & 57.8 \\
\hline Murshidabad & 7102 & 67.5 & 71.0 & 63.9 \\
\hline Nadia & 5168 & 75.6 & 79.6 & 71.4 \\
\hline $\begin{array}{l}\text { North } 24 \\
\text { Parganas }\end{array}$ & 10083 & 85.0 & 88.7 & 81.1 \\
\hline $\begin{array}{l}\text { Paschim } \\
\text { Medinipur }\end{array}$ & 5943 & 79.0 & 86.7 & 71.1 \\
\hline $\begin{array}{l}\text { Purba } \\
\text { Medinipur }\end{array}$ & 5094 & 87.7 & 93.1 & 81.8 \\
\hline Puruliya & 2928 & 65.4 & 78.9 & 51.3 \\
\hline Siliguri & 510 & - & 81.9 & 85.5 \\
\hline $\begin{array}{l}\text { South } 24 \\
\text { Parganas }\end{array}$ & 8153 & 78.6 & 84.7 & 72.1 \\
\hline Uttar Dinajpur & 3001 & 60.1 & 66.7 & 53.2 \\
\hline
\end{tabular}

Source: DISE District Report Card, 2016-17.

The DISE 2016-17 data (Table 1) reveals that out of 21 districts, 10 districts- Purba Medinipur (87.7 percent), Kolkata (87.1 percent), Siliguri (85.5 percent), North 24 Parganas (85.0 percent), Howrah (83.9 per cent), Hoogly (82.6 per cent), Darjeeling (79.9 percent), Paschim Medinipur (79.0 percent), Barddhaman (77.2 percent), South 24 Parganas (78.6 percent), had literacy rates more than the State average literacy rate. It is noteworthy that West Bengal's overall literacy rate (77.1 percent) in 2011 is marginally higher than National literacy rate of 
74.04, meaning that literacy rates of all these ten districts are above national average. The districts of Uttar Dinajpur (60.1 percent), Maldah (62.7 percent), Jalpaiguri (73.8 percent), Dakshin Dinajpur (73.9 percent) and Coch Bihar (75.5 percent) fall in the Uttar Banga region and their literacy rates are below the state average literacy rate. While the districts of Puruliya (65.4 percent), Murshidabad (67.5 percent), Birbhum (70.9 percent), Bankura (71.0 percent) and Nadia (75.6 percent) fall in the Dakshin Banga region and their literacy rates are below the state average literacy rate. Table 1 clearly implies that Purba Medinipur has the highest male literacy rate (93.1 percent) and Uttar Dinajpur has the lowest male literacy rate (66.7 percent) in the period of 2016-17. Table 1 also clearly implies that Kolkata has the highest female literacy rate (85.0 percent) and Puruliya has the lowest female literacy rate (51.3 percent) in period of 2016-17.

Kerala witnessed steady consistency in literacy rate in the period of 2016-2017. According to Census 2011, overall literacy rate of Kerala was 93.9 percent which was much higher than the national overall literacy rate i.e. 74.00 per cent.

Table 2: Literacy Rate in the Districts of Kerala

\begin{tabular}{lllll}
\hline District & $\begin{array}{l}\text { Population } \\
\text { (000's) }\end{array}$ & $\begin{array}{l}\text { Male } \\
\text { Literacy } \\
\text { Rate }\end{array}$ & $\begin{array}{l}\text { Female } \\
\text { Literacy } \\
\text { Rate }\end{array}$ & $\begin{array}{l}\text { Total } \\
\text { Literacy } \\
\text { Rate }\end{array}$ \\
\hline Alappuzha & 2122 & 97.9 & 94.8 & 96.3 \\
Ernaculam & 3280 & 97.1 & 94.3 & 95.7 \\
Idukki & 1107 & 94.8 & 89.6 & 92.2 \\
Kannur & 2526 & 97.5 & 93.6 & 95.4 \\
Kasaragod & 1303 & 93.9 & 86.1 & 89.9 \\
Kollam & 2630 & 95.8 & 92.0 & 93.8 \\
Kottayam & 1979 & 97.2 & 95.7 & 96.4 \\
Kozhikode & 3090 & 97.6 & 93.2 & 95.2 \\
Malappuram & 4111 & 95.8 & 91.6 & 93.6 \\
Palakkad & 2811 & 92.3 & 85.0 & 88.5 \\
Pathanamthitta & 1196 & 97.7 & 96.3 & 96.9 \\
Thiruvanantha- & 3307 & 94.6 & 90.9 & 92.7 \\
puram & & & & \\
Thrissur & 3110 & 97.0 & 93.9 & 95.3 \\
Wayanad & 817 & 92.8 & 85.9 & 89.3 \\
\hline
\end{tabular}

Source: DISE District Report Card, 2016-17.

The DISE 2016-17 data (Table 2) reveals convergence occurring in literacy rates across districts. Out of 14 districts, 7 districts- Pathanamthitta (96.9 percent), Kottayam (96.4 percent), Alappuzha (96.3 percent),
Ernakulam (95.7 percent), Kannur (95.4 percent), Thrissur (95.3 per cent), Kozhikode (95.2 percent) had literacy rates more than the State average literacy rate. It is noteworthy that Kerala's overall literacy rate (93.9 percent) in 2011 is higher than National literacy rate of 74.04 , meaning that literacy rates of all these seven districts are much more above national average. The district of Palakkad occupied the bottom position with 88.5 percent literacy rate while Pathanamthitta occupied the top position with 96.9 percent literacy rate.

Gender wise, a look at the Table 2 clearly implies that Alappuzha has the highest male literacy rate (97.9 percent) and Palakkad has the comparatively lowest male literacy rate (92.3 percent) in the period of 2016-17. Table 2 clearly implies that Pathanamthitta has the highest female literacy rate (96.3 percent) and Palakkad has the lowest female literacy rate (85.0 percent) in the period of 2016-17.

When the researcher looked into the school profile of both the states, data (Table 3 ) reveals that in the period of 2016-17 there were 96432 schools in West Bengal where Kerala had 17144 schools.

Table 3: School Profile of West Bengal and Kerala

\begin{tabular}{lll}
\hline \multirow{2}{*}{ Indicator } & \multicolumn{2}{c}{ State } \\
\cline { 2 - 3 } Schools & West Bengal & Kerala \\
Enrollment & 96432 & 17144 \\
Teachers & 16144562 & 5865210 \\
Schools with head master/ & 565080 & 270218 \\
principal (\%) & 62.59 & 85.42 \\
Single teacher schools (\%) & 4.18 & \\
Single classroom school\% & 5.14 & 2.14 \\
\hline
\end{tabular}

Source: School Education in India- Flash Statistics 2016-17, DISE.

Enrollment and number of teachers in both the states were good. However in West Bengal only $62.59 \%$ schools had headmaster or principal which was much less than Kerala's $85.42 \%$ schools with headmaster or principal. Headmaster plays a significant role in school management. So, his existence is necessary for overall development of a school. Single teacher schools and single classroom schools percentages were also higher in West Bengal than Kerala which certainly is not good enough.

When the researcher looked into the school infrastructure in terms of specific physical facilities 
and equipment of both the states, data (Table 4) reveals that in the period of 2016-17 both West Bengal and Kerala has almost same percentages of schools with building facility $(99.19 \%$ and $99.06 \%$ respectively) and the percentages were good enough.

Table 4: School Infrastructure of West Bengal and Kerala

\begin{tabular}{llc}
\hline \multirow{2}{*}{ Indicator } & \multicolumn{2}{c}{ State } \\
\cline { 2 - 3 } & West Bengal & Kerala \\
\hline $\begin{array}{l}\text { Percentages of Schools with } \\
\text { building }\end{array}$ & 99.19 & 99.06 \\
$\begin{array}{l}\text { Percentages of Schools with } \\
\text { functional drinking water facility }\end{array}$ & 88.46 & 96.73 \\
$\begin{array}{l}\text { Percentages of Schools with } \\
\text { functional toilet for boys }\end{array}$ & 94.85 & 97.69 \\
$\begin{array}{l}\text { Percentages of Schools with } \\
\text { functional toilet for girls }\end{array}$ & 95.98 & 98.98 \\
$\begin{array}{l}\text { Percentages of Schools with } \\
\text { CWSN friendly toilet }\end{array}$ & 11.41 & 26.17 \\
$\begin{array}{l}\text { Percentages of Schools with } \\
\begin{array}{l}\text { Electricity } \\
\text { Percentages of Schools with }\end{array}\end{array}$ & 79.13 & 96.51 \\
$\begin{array}{l}\text { Library } \\
\text { Percentages of Schools with }\end{array}$ & 40.87 & 96.74 \\
$\begin{array}{l}\text { Playground } \\
\text { Percentages of Schools with } \\
\text { Computer in working condition }\end{array}$ & 6.38 & 70.29 \\
\hline
\end{tabular}

Source: School Education in India- Flash Statistics 2016-17, DISE.

$88.46 \%$ schools in West Bengal has functional drinking water facility which is much lower than Kerala's 96.73\% schools. Percentages of schools with functional toilet facility for boys and girls are quite good in both the states though West Bengal had some less percentages of this facility than Kerala. Percentages of schools with CWSN friendly toilet were drastically low in both the states. In the case of electricity and library facility in schools West Bengal was much behind Kerala. Percentages of schools having playground in West Bengal were much less than Kerala. In the case of schools with computer in working condition, percentage of West Bengal schools was very poor in comparison with Kerala.

When the researcher looked into the aspect of teaching and non-teaching staffs in schools of both the states, data (Table 5) reveals that in the period of 2016-17 pupil-teacher ratio in West Bengal was 21 while in Kerala it was 16.
Table 5: Teaching and Non-teaching Staff of West Bengal and Kerala

\begin{tabular}{lll}
\hline \multirow{2}{*}{ Indicator } & \multicolumn{2}{c}{ State } \\
\cline { 2 - 3 } & West Bengal & Kerala \\
\hline Pupil-teacher ratio & 21 & 16 \\
Average teachers per school & 5.9 & 15.1 \\
Female teachers (\%) & 43.0 & 78.4 \\
Non-teaching staff & 34496 & 20208 \\
\hline
\end{tabular}

Source: School Education in India- Flash Statistics 2016-17, DISE.

Average teachers per school were 15.1 in Kerala which is much better than West Bengal's average 5.9. Percentage of female teachers in West Bengal schools was 43.0 which is much lower than Kerala's $78.4 \%$. In the period of 2016-17, there were 34496 non-teaching school staffs in West Bengal while Kerala had 20208 non-teaching staffs.

\section{DISCUSSION}

The study reveals that out of 21 districts, 10 districts- Purba Medinipur, Kolkata, Siliguri, North 24 Parganas, Howrah, Hoogly, Darjeeling, Paschim Medinipur, Barddhaman, South 24 Parganas, had literacy rates more than the State average literacy rate. The districts of Uttar Dinajpur, Maldah, Jalpaiguri, Dakshin Dinajpur and Coch Bihar fall in the Uttar Banga region and their literacy rates are below the state average literacy rate. The districts of Puruliya, Murshidabad, Birbhum, Bankura and Nadia fall in the Dakshin Banga region and their literacy rates are below the state average literacy rate. Purba Medinipur has the highest male literacy rate and Uttar Dinajpur has the lowest male literacy rate in the period of 2016-17. Kolkata has the highest female literacy rate and Puruliya has the lowest female literacy rate in the period of 201617. Paschim Medinipur has the highest number of school in the period of 2016-17 and Siliguri has the lowest number of schools in comparison to other districts of West Bengal. Number of enrolment was highest in South 24 Parganas district while the lowest was in Darjeeling. Girls' enrolment was near about 50 percent in almost all the districts of West Bengal. The present study indicates that in West Bengal most of the districts of Uttar Banga region lag behind the districts of Dakshin Banga region in various aspects of school education. It is a matter of concern. The more capital and administrative 
engagement may be the reason for more educational development of the Dakshin Banga districts.

In Kerala, the study reveals that out of 14 districts 7 districts- Pathanamthitta, Kottayam, Alappuzha, Ernakulam, Kannur, Thrissur, Kozhikode had literacy rates more than the State average literacy rate. Alappuzha has the highest male literacy rate and Palakkad has the comparatively lowest male literacy rate in the period of 2016-17. Pathanamthitta has the highest female literacy rate and Palakkad has the lowest female literacy rate in the period of 2016-17. Girls' enrolment was near about 49 percent in almost all the districts of Kerala.

When the researcher looked into the school infrastructure in terms of specific physical facilities and equipment of both the states, data reveals that in the period of 2016-17 both West Bengal and Kerala has almost same percentages of schools with building facility (99.19\% and $99.06 \%$ respectively) and the percentages were good enough. $88.46 \%$ schools in West Bengal has functional drinking water facility which is much lower than Kerala's $96.73 \%$ schools. Percentages of schools with functional toilet facility for boys and girls are quite good in both the states though West Bengal had some less percentages of this facility than Kerala.

The school profile of both the states reveal that in the period of 2016-17 the enrollment and number of teachers in both the states were good. However in West Bengal, the percentage of schools with headmaster or principal was much less than Kerala's schools with headmaster or principal. Single teacher schools and single classroom schools percentages were also higher in West Bengal than Kerala and this condition should be improved by increasing education budget and planned execution of it. Percentages of schools with CWSN (children with special needs) friendly toilet were drastically low in both the states. Inclusion in the field of education is the call of time. So government and private authorities of both the state should look into the matter. In the case of electricity and library facility, schools having playground and schools with computer in working condition, West Bengal was far behind Kerala. Data reveals that in the period of 2016-17 pupil-teacher ratio, average teachers per schools and existence of female teachers in the schools of West Bengal was not better than Kerala.
Both West Bengal and Kerala have their significance in India's socio-economic, political and educational scenario. In most of the aspects of school education Kerala is in better position than West Bengal. Some facilities in school education are not proper in both the states. Interestingly in case of girls' enrollment percentage in school education, West Bengal is in little bit better place than Kerala.

\section{CONCLUSION}

From this research, following suggestions can be given:

Both the Central government and West Bengal state government should take some positive steps for facilitating educational development in the districts of Uttar Banga region.

$\square$ Enrollment of the girls in school education should be increased in both the states. For that the central government and state governments of West Bengal and Kerala must take some positive initiatives.

$\square$ Both the states should be more concerned about differently abled students. More support systems for children with special needs should be introduced. School education atmosphere should be more inclusive.

More new teachers should be employed in the schools of West Bengal.

$\square$ Electricity and library facility, schools having playground and computer in working condition facilities should be improved in the schools of West Bengal.

$\square$ Both the states should employ more female teachers.

$\square$ The educational policy framers, administrators, teachers and teacher educators may adopts some realistic measures or strategies in the light of the present study.

Dutta (1985) conducted an anthropological appraisal "Primary Education in Calcutta -An Anthropological Appraisal" exploring the cosmopolitan nature of primary education in the capital of West Bengal. Retnakumar \& Ariokyiasamy (2006) conducted a study "Exploring School Enrolment Trends in Kerala" showed enrolling was increasing in private unaided English medium schools rather than government schools. Improving the quality of 
school education was the factor which could sustain the retention of students in government funded schools. The present study on the status of school education between West Bengal and Kerala is not an end in itself; rather it is an ongoing journey to reveal the scenario. Further research work can be done on this topic by including various dimensions of school education.

\section{REFERENCES}

Census of India. 2011. Population Density- Census of India. Retrieved from https://censusindia.gov.in/2011-provresults/data_files/india/Final_PPT_2011_chapter7.pdf

Census of India. 2011. Literacy Rate- Census of India. Retrieved from https://censusindia.gov.in/2011-provresults/data_files/india/Final_PPT_2011_chapter6.pdf
Dutta, B. 1985. Primary Education in Calcutta -An Anthropological Appraisal. (PhD thesis, Calcutta University). In M.B. Buch (Ed.) Survey of Research in Education. $4^{\text {th }}$ Edition.

Elementary Education in India: District Report Cards 2016-17 (DISE). New Delhi: NUEPA.

Elementary Education in India: State Report Card 2016-17 (DISE). New Delhi: NUEPA.

Kamalamma, G. 1969. History and Problems of Primary Education in Kerala (PhD thesis, Kerala University). In M.B. Buch (Ed.) Survey of Research in Education. $1^{\text {st }}$ Edition, 1974.

Retnakumar, J.N. and Ariokyiasamy, P. 2006. Exploring School Enrollment Trends in Kerala. Retrieved from http://sad. sagepub.com/content/1/2/231 